\title{
IDENTIFIKASI KESULITAN BELAJAR SAINS DAN UPAYA YANG DILAKUKAN GURU SEKOLAH MENENGAH UNTUK MENGATASINYA
}

\author{
Reni Marlina ${ }^{1 *}$ \\ ${ }^{1}$ Pendidikan Biologi Fakultas Keguruan dan Ilmu Pendidikan Universitas Tanjungpura, Pontianak, \\ Indonesia \\ *email: reni.marlina@kip.untan.ac.id
}

Received: 1 April 2020 Accepted: 20 Juni 2020 Published: 30 Juni 2020

\begin{abstract}
Abstrak
Tujuan dari penelitian ini adalah untuk mengidentifikasi kesulitan belajar pada siswa khususnya pada pelajaran sains. Metode yang digunakan adalah deskriptif dengan pendekatan survei. Instrumen yang digunakan adalah kuesioner. Subjek penelitian adalah guru yang yang aktif dalam kelompok Musyawarah Guru Mata Pelajaran (MGMP) Biologi di Kabupaten Kayong Utara dan Kota Singkawang. Data dianalisis dengan menggunakan statistik deskriptif. Hasil yang diperoleh diketahui kesulitan belajar yang dialami siswa saat belajar di Kayong Utara dan Singkawang. yaitu kurang konsentrasi, sulit memahami materi, tidak mandiri dalam belajar dan sulit mengingat materi. Dari 27 guru sains, 26 guru menyatakan media TIK mewakili media yang dipilih guru untuk mengatasi ke 7 kesulitan belajar tersebut. para guru memiliki keinginan kuat untuk mengintegrasikan TIK ke dalam proses belajar-mengajar walaupun sulit diaplikasikan. Hambatan utama adalah kurangnya komputer di ruang kelas, dan internet kecepatan rendah. Penting bagi pelatih guru dan pembuat kebijakan untuk memahami hambatan penggunaan TIK di kelas. Sehingga strategi pembelajaran dengan menggunakan media TIK dapat tepat bagi siswa dan guru.
\end{abstract}

Kata kunci: guru sains, kesulitan belajar, TIK

\begin{abstract}
The purpose of this study is to identify learning difficulties in students, especially in science subjects. The method used is descriptive survey approach. The instrument used was a questionnaire. The subjects of the study were the teachers who were active in the Biology Teacher Group (MGMP) in Kayong Utara Regency and Singkawang City. Data were analyzed using descriptive statistics. The results obtained are known to learn difficulties experienced by students while studying in Kayong Utara and Singkawang. That is a lack of concentration, difficulty understanding the material, not being independent in learning, and difficulty remembering the material. From 27 science teachers, 26 teachers stated that ICT media represented the media chosen by the teacher to overcome the 7 learning difficulties. Teachers have a strong desire to integrate ICT into the teaching and learning process even though it is difficult to apply. The main obstacles are the lack of computers in the classroom and low-speed internet. It is important for teacher trainers and policymakers to understand the obstacles to using ICT in the classroom. So that learning strategies using ICT media can be right for students and teachers.
\end{abstract}

Keywords: learning difficulties, science teacher, ICT

How to cite (in APA style): Marlina, R. (2020). Identifikasi kesulitan belajar sains dan upaya yang dilakukan guru sekolah menengah untuk mengatasinya. Jurnal Pendidikan Informatika dan Sains, 9(1), 13-20. 


\section{PENDAHULUAN}

Dalam pembelajaran sains, siswa dihadapkan pada materi abstrak, istilah asing, dan nama ilmiah. Ini adalah salah satu penyebab pelajaran ini lebih sulit untuk dipelajari. Dengan mempelajari jenis kesulitan belajar siswa dan faktor-faktor yang mempengaruhinya, guru dapat memberikan pencegahan yang sesuai dengan jenis kesulitan belajar siswa. Guru juga dapat meningkatkan profesionalisme mereka dalam mengajar sehingga dapat mengurangi kesulitan belajar sains. Bassett and Smith (1996) berpendapat bahwa kesulitan belajar adalah ketidakmampuan yang mempengaruhi bagaimana siswa rata-rata hingga di atas rata-rata memproses informasi (menerimanya, mengintegrasikannya, dan/atau mengungkapkannya). Siswa dengan kesulitan belajar mungkin memiliki masalah berbasis bahasa dan/atau persepsi yang mempengaruhi penulisan, bahasa, membaca, mengeja, atau matematika.

Mengungkap dan mengidentifikasi kesulitan yang dialami siswa saat belajar sains berdasarkan pada persepsi guru yang tergabung dan aktif di MGMP penting untuk dilakukan. Persepsi dan pandangan guru dalam mengajar khususnya dalam mengidentifikasi kesulitan belajar siswa sangat dibutuhkan untuk menentukan metode dan strategi yang tepat dalam mendidik agar proses belajar mengajar di kelas menjadi lebih bermakna. Selain itu terdapat dua alasan yang menuntut pentingnya kesulitan belajar sains untuk diidentifikasi. Alasan pertama adalah menemukan permasalahan dalam pelaksanaan pembelajaran sekolah yang berkembang saat ini yang akan menjadi dasar untuk melakukan refleksi diri (Jiang, 2017). Alasan berikutnya adalah dapat menjadi dasar penelusuran miskonsepsi dalam pembelaajran sains selama ini (Arnab, 2017). Pada pembelajaran sains, guru harus memahami bahwa pelajaran ini tidak hanya kumpulan fakta atau konsep, tetapi juga kumpulan proses dan nilai-nilai yang dapat dikembangkan dalam kehidupan nyata. Banyak siswa tidak dapat mengembangkan pemahaman mereka tentang konsep pelajaran ini karena pengetahuan dan proses tidak terintegrasi dengan baik sehingga siswa mengalami kesulitan dalam pembelajaran sains. Kesulitan yang sering dialami berdasarkan percakapan siswa sains termasuk kesulitan dalam memahami konsep sains, kesulitan dalam membaca kalimat asing dan istilah, dan kesulitan dalam menggunakan alat (Haryono, 2013). Hal utama dan tantangan dalam perencanaan pembelajaran adalah menentukan media yang dapat digunakan untuk menyampaikan materi (Dick \& Carey, 1985). Penentuan media akan digunakan dalam pembelajaran berdasarkan materi apa yang akan dibahas, bagaimana cara bertanya, bagaimana cara mengevaluasinya dan siapa siswa. Oleh karena itu kemampuan guru harus ditingkatkan dalam proses dan hasil pembelajaran (Roy, 1998). Dari pengamatan awal pada awal Oktober 2018, peneliti melihat kenyataan di SMA Simpang Hilir Kayong Utara ketika pembelajaran sains berlangsung. Terlihat bahwa tidak semua siswa aktif dalam menghubungkan konsep-konsep baru dari eksperimen mereka, masih ada 11 siswa yang mengalami kesulitan belajar dari total siswa (28 siswa). Ini karena dalam proses belajarnya siswa masih tidak peduli dalam melakukan kegiatan eksperimen dan sikap mereka yang suka mengajak teman ngobrol, tidak mau mencoba eksperimen mereka dan tidak percaya diri dalam melakukan eksperimen. Berdasarkan hasil studi mereka, ada 8 siswa yang mendapat skor mata pelajaran IPA di bawah kriteria ketuntasan minimum (KKM).

Data yang diperoleh dari kelas VIII SMP di Kayong Utara menunjukkan bahwa siswa mengalami kesulitan belajar dalam materi sains. Selain itu, berdasarkan pengamatan oleh peneliti ketika mengamati di salah satu sekolah menengah pertama di Kabupaten Singkawang diperoleh informasi bahwa pembelajaran sains kurang memanfaatkan lingkungan sekitar dan laboratorium untuk mendukung proses pembelajaran terutama pada konsep abstrak yang memerlukan eksperimen. Media dan metode pembelajaran yang digunakan oleh guru juga masih belum beragam, sehingga beberapa siswa mengalami kesulitan memahami materi pelajaran ini. Berdasarkan hasil pengamatan pendahuluan, data yang diperoleh dari keseluruhan siswa kelas VII berjumlah 32 siswa, ada 13 yang rata-rata skor IPAnya di bawah KKM yaitu kurang dari 70. Ingat kondisi ini, perlu untuk melakukan penelitian tentang jenis kesulitan belajar dan jenis media yang dapat digunakan guru sebagai upaya 
untuk mengatasinya. Hasil mendiagnosis kesulitan belajar pada siswa berguna dalam merencanakan tindakan yang tepat dalam sebuah penelitian. Penelitian ini juga diharapkan menjadi input bagi guru untuk menentukan media pembelajaran yang tepat dalam pembelajaran sehingga dapat mengurangi tingkat kesulitan pembelajaran sains. Ini sesuai dengan persyaratan guru sehingga dapat dikatakan profesional yaitu dapat menggunakan keterampilan diagnostik dan memilih media yang tepat untuk membantu siswa yang mengalami masalah akademik.

Baru-baru ini, banyak ruang kelas konvensional tidak menggunakan alat pengajaran, Yelland (2001) berpendapat bahwa lingkungan di ruang kelas tradisional tampaknya tidak memiliki manfaat untuk mempersiapkan peserta didik agar produktif di masa depan mereka. Pernyataan yang didukung oleh Grimus (2000) menyatakan bahwa dengan mengajarkan keterampilan TIK, para siswa dipersiapkan untuk mengembangkan kemampuan mereka berdasarkan pemahaman yang baik. Selanjutnya, Bransford et al. (2000) berpendapat bahwa pembelajaran memberikan pedoman penting untuk penggunaan teknologi dapat mengembangkan kompetensi siswa dan guru yang diperlukan untuk revolusi 4.0. Selain itu, Posthill and Roffman (1991) menyatakan bahwa banyak siswa jarang diberikan penjelasan tentang kesulitan belajar mereka. Allen (1996) berpendapat bahwa 40\% kesulitan belajar siswa berhasil sampai ke sekolah menengah tanpa didiagnosis masalah mereka. Reis, at al. (1994) menemukan banyak kesulitan belajar siswa yang sering dianggap oleh gurunya sebagai sekadar malas atau tidak memperhatikan detail. Greenbaum, et al. (1995) melaporkan bahwa siswa yang diwawancarai tentang pengalaman pendidikan mereka menemukan bahwa guru terkadang kurang mendapat informasi tentang siswa yang mengalami ketidakmampuan belajar di kelas mereka.

\section{METODE}

Penelitian ini menggunakan metode deskriptif dengan pendekatan survei dan analisis kuantitatif. Sampel penelitian dipilih dari kelompok diskusi guru mata pelajaran sains Kabupaten Kayong Utara dan Kota Singkawang Kalimantan Barat Indonesia. Terdapat 27 guru yang menjadi subjek dalam penelitian ini. Instrumen yang digunakan adalah lembar wawancara dan kuesioner persepsi guru tentang kesulitan belajar sains. Kuesioner didistribusikan kepada 27 guru secara acak sebagai subjek penelitian. Subjek diberi waktu lima hari untuk mengisi kuesioner dan mengembalikannya kepada peneliti. Penskoran kuesioner didasarkan pada 5 poin skala likert mulai dari: 5 = selalu, $4=$ sering, $3=$ kadang-kadang, $2=$ jarang, dan $1=$ tidak pernah. Pernyataan yang diberikan berdasarkan persepsi mereka. Berbagai bagian kuesioner meliputi: (a) data pribadi, (b) masalah dengan konsentrasi siswa di pembelajaran sains, (c) kemandirian siswa dalam belajar, (d) fasilitas TIK, dan (e) peran TIK dalam menciptakan iklim kelas yang positif. Data yang diperoleh dianalisis menggunakan statistic deskriptif dan dilengkapi penjelasan secara naratif.

\section{HASIL DAN PEMBAHASAN}

Ada tujuh kesulitan belajar yang dialami oleh siswa selama pembelajaran sains di Kabupaten Kayong Utara dan Kota Singkawang berdasarkan persepsi guru sains. Kesulitan belajar yang dialami siswa termasuk susah konsentrasi, tidak berusaha lebih keras dalam mempelajari materi, tidak mandiri dalam belajar, mengalami kesulitan memahami materi, mengalami kesulitan mengingat materi, tidak mau bekerja sama, dan sering mengganggu teman-teman lain saat belajar. Pembelajaran sains yang diukur adalah pada konsep sistem pencernaan dan sistem pernapasan di sekolah menengah. Tabel 1 menunjukkan latar belakang demografi peserta. Temuan demografis di mana kategori usia di bawah 25 terdapat 3 guru (11\%), usia 26-35 terdapat 9 guru (34\%), usia 36-45 terdapat 12 guru (44\%), usia 46-55 terdapat 2 guru (7\%), dan usia diatas 55 ada 1 orang (4\%). Sebaran subjek yang berjenis kelamin laki-laki ada $22 \%$ dan perempuan sebesar $78 \%$. Pengalaman berdasarkan tahun pengalaman terdapat 1 orang subjek yang mengajar kurang dari 1 tahun. Pengalaman antara $1-4$ tahun sebanyak 8 guru, $5-10$ tahun sebesar $52 \%$. Terdapat 2 orang yang 
mengajar antar 10 sampai 20 tahun, dan yang telah mengajar lebih dari 20 tahun ada 2 orang. Analisis etnis menunjukkan bahwa frekuensi Melayu adalah 52\%, tionghua 5\%, bugis dan dayak 4\%, dan jawa sebanyak $33 \%$.

Tabel 1. Karakteristik Subjek Penelitian

\begin{tabular}{cccc}
\hline Faktor & Kategori & Frekuensi & Persentase (\%) \\
\hline Umur & $<25$ & 3 & 11 \\
& $26-35$ & 9 & 34 \\
& $36-45$ & 12 & 44 \\
& $46-55$ & 2 & 7 \\
& $55+$ & 1 & 4 \\
\hline Jenis & Male & 6 & 22 \\
Kelamin & Female & 21 & 78 \\
\hline Pengalaman & Less than 1 & 1 & 4 \\
& year & & \\
& $1-4$ years & 8 & 30 \\
& $5-10$ years & 14 & 52 \\
& $10-20$ years & 2 & 7 \\
& 20 years + & 2 & 7 \\
\hline Etnis & Melayu & 14 & 52 \\
& Tionghua & 2 & 7 \\
& Bugis & 1 & 4 \\
& Dayak & 1 & 4 \\
& Jawa & 9 & 33 \\
\hline
\end{tabular}

Persepsi guru dalam pembelajaran sains baik dari aspek siswa maupun fasilitas TIK disajikan pada Tabel 2. Berdasarkan informasi yang diberikan pada Tabel 2, rata-rata keseluruhan menunjukkan tingkat sedang. Untuk pernyataan "Siswa lebih berkonsentrasi pada pembelajaran mereka" $(\mathrm{M}=2.02, \mathrm{SD}=.943), 12 \%$ responden selalu, 10\% sering, 3\% kadang-kadang, 2\% jarang, dan $0 \%$ tidak pernah. Untuk pernyataan "Siswa berusaha lebih keras dalam apa yang mereka pelajari," $(\mathrm{M}=1,97, \mathrm{SD}=0,810)$ selalu, $11 \%$ responden selalu, $9 \%$ sering, $6 \%$ kadang-kadang, $1 \%$ jarang, dan $0 \%$ tidak pernah. "Siswa merasa mandiri dalam pembelajaran sains (mereka dapat mengulangi materi jika diperlukan, mengeksplorasi dalam pelajaran yang lebih detail yang mereka minati, dll.)" ( $\mathrm{M}=2.32, \mathrm{SD}=.973), 14 \%$ responden selalu, 5\% sering , 2\% terkadang, 6\% jarang, dan $0 \%$ tidak pernah. "Siswa lebih memahami apa yang mereka pelajari" $(\mathrm{M}=2.05, \mathrm{SD}=.989)$, 17\% responden selalu, 7\% sering, 3\% kadang-kadang, 0\% jarang dan 0\% tidak pernah. Siswa lebih mengingat apa yang telah mereka pelajari " $(\mathrm{M}=2.02, \mathrm{SD}=.943), 15 \%$ responden selalu, $4 \%$ sering, 4\% kadang-kadang, 4\% jarang, dan 0\% tidak pernah. "TIK memfasilitasi kolaborasi antar siswa" (M $=1,98, \mathrm{SD}=0,820)$, responden selalu $5 \%$, sering $6 \%$, kadang-kadang $12 \%$, jarang $5 \%$, dan $0 \%$ tidak pernah. Akhirnya, "TIK meningkatkan iklim kelas (siswa lebih terlibat, lebih sedikit mengganggu)" $(\mathrm{M}=2,04, \mathrm{SD}=0,983)$, responden selalu 4\%, 8\% sering, 6\% kadang-kadang, 9\% jarang, dan 0\% tidak pernah. Tingkat rata-rata pernyataan ekspresi berada di antara 1,97 hingga 2,32. Sementara rata-rata keseluruhan kendala adalah $\mathrm{M}=2.06, \mathrm{SD}=.923$ yang berada pada tingkat sedang.

Berdasarkan temuan ini, kesulitan belajar sains berdasarkan persepsi guru dapat diatasi dengan mengimplementasikan media TIK dalam pengajaran dan pembelajaran di kelas. Guru menyatakan bahwa menggunakan TIK di kelas merupakan tantangan yang besar dan mengakui bahwa media berbasisi TIK sangat efektif dalam mendukung proses belajar mengajar. Salah satu masalah dalam penerapan TIK sebagai alat pengajaran dalam proses belajar mengajar adalah penerimaan guru, yang pada gilirannya dipengaruhi oleh sikap mereka terhadap media ini. Sikap guru telah dianggap sebagai salah satu faktor penghambat penerapan TIK di kelas. Keberhasilan penggunaan teknologi di 
kelas sangat tergantung pada bagaimana sikap guru terhadap media ini. Bahkan, sikap guru terhadap alat pengajaran seperti TIK mempengaruhi strategi mereka di kelas (Hieftje, 2016). Banyak penelitian dalam masalah integrasi TIK dalam pendidikan menemukan bahwa guru enggan dengan teknologi baru dan hal ini menjadi masalah yang signifikan. Watson (1999) berpendapat bahwa mengintegrasikan teknologi baru sebagai media ke dalam pengaturan pendidikan memerlukan perubahan. Menurutnya mempertimbangkan perbedaan sikap guru untuk berubah adalah penting karena keyakinan guru mempengaruhi apa yang mereka lakukan di ruang kelas. Becta (2004) mengklaim bahwa satu area utama dari sikap guru terhadap penggunaan teknologi adalah pemahaman mereka tentang bagaimana teknologi ini akan bermanfaat bagi pengajaran mereka dalam materi sains dan siswa mereka dalam belajar di kelas. Schoepp (2005) menemukan bahwa walaupun guru merasa ada lebih dari cukup teknologi yang tersedia, mereka tidak percaya bahwa mereka didukung, atau dibimbing dalam integrasi teknologi ke dalam pengajaran sains mereka.

Tabel 2. Persepsi Guru Dalam Belajar Sains

\begin{tabular}{|c|c|c|c|c|c|c|c|c|}
\hline No & Item & Selalu & Sering & $\begin{array}{l}\text { Kadang- } \\
\text { kadang }\end{array}$ & Jarang & $\begin{array}{l}\text { Tidak } \\
\text { Pernah }\end{array}$ & Mean & $\mathrm{SD}$ \\
\hline 1 & $\begin{array}{l}\text { Siswa lebih } \\
\text { berkonsentrasi } \\
\text { dalam belajar }\end{array}$ & 12 & 10 & 3 & 2 & 0 & 2.02 & .943 \\
\hline 2 & $\begin{array}{l}\text { Siswa mencoba } \\
\text { dengan gigih apa } \\
\text { yang dipelajari }\end{array}$ & 11 & 9 & 6 & 1 & 0 & 1.97 & .810 \\
\hline 3 & $\begin{array}{l}\text { Siswa merasa } \\
\text { mandiri dalam } \\
\text { belajar, dapat } \\
\text { mengulang secara } \\
\text { mandiri }\end{array}$ & 14 & 5 & 2 & 6 & 0 & 2.32 & .973 \\
\hline 4 & $\begin{array}{l}\text { Siswa lebih } \\
\text { mudah paham apa } \\
\text { yang dipelajari }\end{array}$ & 17 & 7 & 3 & 0 & 0 & 2.05 & .989 \\
\hline 5 & $\begin{array}{l}\text { Siswa lebih } \\
\text { mudah mengingat } \\
\text { apa yang mereka } \\
\text { pelajari }\end{array}$ & 15 & 4 & 4 & 4 & 0 & 2.02 & .943 \\
\hline 6 & $\begin{array}{l}\text { Fasilitas TIK } \\
\text { dapat menunjang } \\
\text { kolaborasi antar } \\
\text { siswa }\end{array}$ & 5 & 6 & 12 & 5 & 0 & 1.98 & .820 \\
\hline 7 & $\begin{array}{l}\text { TIK } \\
\text { meningkatkan } \\
\text { iklim kelas }\end{array}$ & 4 & 8 & 6 & 9 & 0 & 2.04 & .983 \\
\hline
\end{tabular}

Studi ini mengungkapkan bahwa 100\% guru sains memiliki keterampilan dalam menggunakan komputer di kelas, tetapi mereka masih menggunakan sedikit teknologi karena mereka tidak memiliki cukup waktu untuk merencanakan pelajaran mereka menggunakan media TIK. 20 guru sains mengidentifikasi keterbatasan waktu sebagai salah satu kesulitan dalam menjadwalkan penggunaan TIK di dalam kelas. Menurut Becta (2004) masalah kurangnya waktu guru disebabkan karena guru memiliki banyak tanggung jawab lain yang mungkin masih bersifat administrasi. Hal ini mempengaruhi mereka untuk enggan merancang penggunaan TIK di kelas. Beberapa guru sains 
yang berpartisipasi secara spesifik menyebutkan bahwa mereka memerlukan banyak waktu untuk mencari informasi internet, menyiapkan strategi dan bahan, mengeksplorasi dan berlatih menggunakan teknologi, menangani masalah teknis, dan bergabung dengan pelatihan yang memadai. Studi terbaru menunjukkan bahwa kurangnya waktu merupakan faktor penting yang mempengaruhi penerapan teknologi baru (TIK) dalam pendidikan, guru khususnya guru sains membentuk keyakinan mereka sendiri tentang peran TIK sebagai alat pengajaran, kepercayaan diri dan kompetensi pribadi mereka (Prestridge, 2007). Hambatan ada dalam mengintegrasikan TIK dalam proses belajar mengajar (Ertmer, 2005) yang bersifat ekstrinsik bagi guru dan termasuk kurangnya waktu, sumber daya, akses, dan dukungan teknis (Kelley \& Knowles, 2016).

Temuan penelitian ini menunjukkan bahwa guru masih memberikan komentar tentang hambatan dalam menerapkan alat pengajaran di sekolah dalam proses belajar mengajar. Hasil penelitian Cachia and Ferrari (2010) menunjukkan bahwa guru memang menggabungkan banyak sumber daya dalam proses pengajaran mereka di kelas, serta memanfaatkan berbagai model TIK dengan hampir dua pertiga mengklaim menggunakan teknologi dan situs web (Schnittka et al., 2016). Buku teks dianggap dasar dalam sistem pendidikan (Guzey et al., 2016). Hampir dua pertiga responden kami sering mengikuti buku teks dalam proses pengajaran mereka. Teknologi penting untuk pembelajaran seperti komputer dan perangkat lunak pendidikan diberi peringkat sebagai teknologi teratas (Cachia \& Ferrari, 2010; Yanyan et al., 2016). Di sisi lain, penelitian kami menunjukkan bahwa tingkat penggunaan TIK guru sains berada diatas rata-rata. Namun, hasil penelitian memberikan informasi bahwa lebih banyak guru menggunakan TIK dengan perangkat lunak pengajaran di kelas untuk menyajikan atau menunjukkan contoh kepada siswa. Mereka juga suka menggunakan komputer untuk mengakses hasil siswa dan melacak kemajuan mereka di kelas.

Terlepas dari upaya saat ini dalam integrasi TIK dalam proses pembelajaran sains, banyak sekolah khususnya di daerah pedesaan masih tidak tahu bagaimana menggunakan alat TIK dalam pembelajaran sehari-hari mereka (Eleftheriou, 2017). Mereka bahkan tidak tahu bagaimana memeriksa hasil siswa mereka dalam sistem yang ada seperti program microsoft excel atau microsoft word. Tidak semua sekolah memiliki komputer dan fasilitas internet untuk digunakan setiap hari. Tantangan utama adalah untuk menyediakan alat TIK yang tepat untuk daerah perkotaan dan pedesaan secara efisien. Studi ini akan menawarkan informasi yang tak ternilai ke administrasi sekolah serta kepada pembuat kebijakan pendidikan mengenai sifat kontribusi TIK untuk proses belajar mengajar terutama di kelas sains. Karena sikap dan persepsi guru sains sangat penting untuk seberapa efektif suatu inovasi diterapkan, penting untuk mengukur bagaimana guru memandang inovasi ini dan peran positifnya sebagai alat pengajaran untuk meningkatkan proses belajar mengajar. Diharapkan juga bahwa studi ini akan berkontribusi pada basis pengetahuan yang berkembang dan generasi revolusi 4.0 mengenai penggunaan TIK dalam pendidikan di Indonesia. Jika hambatan yang dihadapi oleh guru dapat diatasi, itu adalah langkah maju untuk meningkatkan proses pembelajaran sains dan hasil belajar siswa (Kashibuchi, 2015).

\section{SIMPULAN}

Ada tujuh kesulitan belajar yang dialami oleh siswa selama pembelajaran sains di Kabupaten Kayong Utara dan Kota Singkawang berdasarkan persepsi guru sains. Kesulitan belajar yang dialami siswa termasuk susah konsentrasi, tidak berusaha lebih keras dalam mempelajari materi, tidak mandiri dalam belajar, mengalami kesulitan memahami materi, mengalami kesulitan mengingat materi, tidak mau bekerja sama, dan sering mengganggu teman-teman lain saat belajar. Guru menyatakan bahwa TIK adalah alat pengajaran yang dipilih untuk mengatasi tujuh kesulitan belajar tersebut.

\section{REFERENSI}

Allen, V. (1996). A disability crutch collegians claim learning disabilities to get special favors. USA: Today. 
Arnab. (2017). Towards a trans-disciplinary methodology for a game based intervention process.Educ.Technol,48, 279-312.

Bassett, D. S., \& Smith, B. C. (1996). Transition in an era of reform. Journal of Learning Disabilities, 29(2), 161-166.

Becta, (2004). The impact of information and communication technologies on learning and attainment. Full report, March 2003.

Bransford, J., Brown, A. L., \& Cocking, R. R. (2000). How people learn: brain, mind, experience, and school (2nd ed.). Washington, D.C.: National Academy Press. https://www.msu.edu/ towlehje/How\%20People\%20Learn.pdf

Cachia, R., \& Ferrari, A. (2010). Creativity in schools: A survey of teachers in Europe. Luxe mbourg: Publications Office of the European Union.

Dick, W \& Carey, L. (1985). The systematic design of instructional. London: Scoot, Foresman and Company.

Eleftheriou. (2017). Using computer simulations for investigating a sex education intervention: An exploratory study. JMIR Serious Games, 5, e9.

Ertmer, P. (2005). Teacher pedagogical beliefs: The final frontier in our quest for technology Integration. Educational Technology, Research and Development, 53 (4), 25-40.

Greenbaum, B., Graham, S., \& Scales, W. (1995). Adults with learning disabilities:Educational and social experiences during college, Exceptional Children, 61, 460-471.

Grimus, M. (2000). ICT and multimedia in the primary school. Paper presented at the 16th conference on educational uses of information and communication technologies, Beijing: China. http://www.pcnews.at/d/_pdf/n700034.pdf

Guzey, S. S., Moore, T. J., Harwell, M., \& Moreno, M. (2016). STEM integration in middle school life science: student learning and attitudes. Journal of Science Education and Technology, 25(4), 550-560.

Haryono. (2013). Pembelajaran IPA yang menarik dan mengasyikan. Yogyakarta: Kepel Press Puri Arsita A-6.

Hieftje, K. (2016). Development of an HIV prevention videogame intervention: Lessons Learned. Int. J. Serious Games, 3, 83-90.

Jiang, R. (2017). Interative design and testing for the development of a game-based chlamydia awareness intervention: A pilot study. Games Health J. 6, 205-216.

Kashibuchi, M. (2015). The educational effectiveness of a simulation/game in sex education. Simul Gaming, 32, 331-343.

Kelley, T. R., \& Knowles, J. G. (2016). A conceptual framework for integrated STEM education. International Journal of STEM Education, 3(1), 1-11.

Posthill, S. M. \& Roffman, A. J. (1991). The impact of a transitional training program for young adults with learning disabilities. Journal of Learning Disabilities, 24, 619-629.

Prestridge, S. (2007). Engaging with the transforming possibilities of ICT. Australian Educational C omputing, 22 (2), 3-9.

Reis, S. M., Neu, T. W. \& McGuire, J. M. (1994). Case studies of high-ability students with learning disabilities who have achieved. Exceptional Children, 63, (4), 463-479.

Roy, K. (1998). Effective Teaching Strategies. Australia: Social Science Press.

Schnittka, C. G., Evans, M. A., Won, S. G. L., \& Drape, T. A. (2016). After-School Spaces: Looking for learning in all the right places. Research in Science Education, 46(3), 389-412.

Schoepp, K. (2005). Barriers to technology integration in a technology-rich environment.

Learning and Teaching in Higher Education. Gulf Perspectives, 2(1), 1-24.

Watson, G. (1999). Barriers to the integration of the Internet into teaching and learning: Professional development. Paper presented at the Asia Pacific Regional Internet 
Conference on Operational Technologies.www.apricot.net/apricot99/Singapore_paperWatson.doc.

Yanyan, L., Zhinan, H., Menglu, J., \& Ting-Wen, C. (2016). The effect on pupil's science performance and problem-solving ability through lego: an engineering design-based modeling approach. Journal of Educational Technology \& Society, 19(3) 156.

Yelland, N. (2001). Teaching and learning with information and communication technologies (ICT) for numeracy in the early childhood and primary years of schooling. Australia: Department of Education, Training and Youth Affairs. http://www.dest.gov.au/archive/research/fellowship/docs/Nicola_Yelland/Yelland_report. pdf. 